\title{
Effectiveness of COVID-19 Vaccines: Eight Months Post Single Dose Vaccination
}

Naif Khalaf Alharbi ${ }^{1,2, *}$, Jaffar A. Al-Tawfiq ${ }^{3,4,5}$, Suliman Alghnam ${ }^{1,2}$, Amal Alwehaibe $^{1}$, Abrar Alasmari ${ }^{6}$, Suliman A. Alsagaby ${ }^{7}$, Faizah Alotaibi ${ }^{1}$, Faisal Alsubaie ${ }^{8}$, Majid Alshomrani ${ }^{2,9}$, Fayssal M. Farahat ${ }^{2,9}$, Mohammad Bosaeed ${ }^{1,2,9}$, Ahmad Alharbi ${ }^{9}$, Omar Aldibasi ${ }^{1,2}$, Abdullah M. Assiri $^{8}$

${ }^{1}$ King Abdullah International Medical Research Center (KAIMRC), Riyadh, Saudi Arabia

${ }^{2}$ King Saud bin Abdulaziz University for Health Science (KSAU-HS), Riyadh, Saudi Arabia

${ }^{3}$ Specialty Internal Medicine and Quality Department, Johns Hopkins Aramco Healthcare, Dhahran, Saudi Arabia

${ }^{4}$ Infectious Disease Division, Department of Medicine, Indiana University School of Medicine, Indianapolis, IN, USA

${ }^{5}$ Infectious Disease Division, Department of Medicine, Johns Hopkins University School of Medicine, Baltimore, MD, USA

${ }^{6}$ Department of Infectious Disease Epidemiology, London School of Hygiene \& Tropical Medicine, Keppel Street, London WC1E 7HT, UK.

${ }^{7}$ Department of Medical Laboratory Sciences, College of Applied Medical Sciences, Majmaah University, Al Majmaah-11952, Saudi Arabia

${ }^{8}$ Assistant Agency for Preventive Health, Ministry of Health, Riyadh, Saudi Arabia

${ }^{9}$ King Abdulaziz Medical City (KAMC), Ministry of National Guard - Health Affairs (MNG-HA), Riyadh, Saudi Arabia

*Corresponding Author: harbina2@ngha.med.sa

Short title: Outcomes of COVID-19 vaccines from Pfizer-BioNTech and Oxford-AstraZeneca vaccine.

Keywords: Effectiveness; COVID-19; vaccines; Pfizer-BioNtech BNT162b2 and AstraZenecaOxford AZD1222 
medRxiv preprint doi: https://doi.org/10.1101/2021.09.18.21263262; this version posted September 22, 2021. The copyright holder for this

\section{Abstract}

Objectives: To describe the real-world data on the effectiveness of Pfizer-BioNtech BNT162b2 and AstraZeneca-Oxford AZD1222 vaccines against COVID-19 in a large cohort in the Kingdom of Saudi Arabia (KSA).

Methods: A total of 18,543 subjects received a single-dose of either of the vaccines at one vaccination centre in $\mathrm{KSA}$, and were followed up for three to eight months. Clinical data from medical records, adverse events (AEs) from a self-reporting system, and COVID-19 infection data from the national databases were retrieved and analysed.

Results: Subjects median age was 33 years old with an average of 27.3 body mass index and the majority were male $(60.1 \%) .92 .17 \%$ of the subjects had no COVID-19 infection postvaccination. Diabetes mellitus $(p=0.0325)$, organ transplantation $(p=0.0254)$, and morbid obesity $(p=0.0014)$ were risk factors for infection post-vaccination. Unlike vaccine type, being Saudi, male, or obese was more likely to get the infection earlier. AE reports from 1084 subjects included injection site pain, fatigue, fever, myalgia, headache.

Conclusion: Single-dose COVID-19 vaccines in KSA showed an effectiveness rate of $92.17 \%$ up to eight months follow-up. The rate for AZD1222 was higher than what have been previously reported. Side effects and AEs were within what has been reported in clinical trials. 
medRxiv preprint doi: https://doi.org/10.1101/2021.09.18.21263262; this version posted September 22, 2021. The copyright holder for this

\section{Introduction}

A novel Severe Acute Respiratory Syndrome Coronavirus-2 (SARS-CoV-2) emerged in Wuhan, China in 2019 and spread globally (1). The disease is known as coronavirus infectious disease 2019 (COVID-19) (2). In March 2020, the World Health Organization (WHO), declared COVID19 as a global pandemic and a public health emergency of international concern (3). SARSCoV-2 is highly contagious and transmitted through human-to-human contact (3). Most COVID19 cases $(81 \%)$ are asymptomatic or present with mild to moderate symptoms(4). However, other cases are severe (14\%) to critical pneumonia (5\%); with a fatality rate of $2-3 \%(4)$. As of $5^{\text {th }}$ of September 2021, more than 222 million confirmed cases of COVID-19 and 4.5 million deaths were reported globally (5). To reduce the risk of SARS-CoV-2 transmission, preventive strategies have been implemented, including the use of face masks, hand washing/hygiene, contact tracing, travel bans, and government-led cancellation of unnecessary activities (6).

Importantly, prophylactic vaccines are sought as the ultimate intervention to bring the pandemic under control. Over 200 vaccine candidates for COVID-19 were at various stages of clinical development (7). Of these, at least 50 candidate vaccines made it into human trials. To date, several vaccines have been approved by regulatory authorities, based on clinical trials that demonstrated a high safety profile and variable efficacy rates (7). The results of phase III clinical trials showed 95\% efficacy for the Pfizer-BioNtech BNT162b2 vaccine, 92\% for the Gamaleya SputnikV vaccine, $94.5 \%$ for Moderna mRNA-1273 vaccine, $70 \%$ for the AstraZeneca-Oxford AZD1222 vaccine, and 97\% for Sinopharm BIBP COVID-19 vaccine (7-9).

Several different vaccine technologies have been used to develop the COVID-19 vaccines (10), including mRNA $(11,12)$, adenoviral vectored vaccines $(13,14)$, inactivated virus (15), and adjuvanted spike glycoprotein (16). The BNT162b2 vaccine is based on the lipid nanoparticleencapsulated nucleoside-modified messenger RNA (mRNA) that encodes the SARS-CoV-2 
spike (S) glycoprotein (17), while the AZD1222 vaccine is based on the ChAdOx1 adenoviral vector encoding the SARS-CoV-2 spike (S) glycoprotein (10). The Kingdom of Saudi Arabia (KSA) was among the first countries to launch an accelerated program for COVID-19 vaccination (18). The approved COVID-19 vaccines that are being used in KSA are the PfizerBioNtech BNT162b2 vaccine, Moderna mRNA-1273 vaccine, and AstraZeneca-Oxford AZD1222 vaccine (19).

For each vaccine candidate, there were a number of vaccine controlled randomised clinical trials focusing on evaluating safety, immunogenicity, and efficacy $(7,20)$, which were the basis for regulatory approvals. However, to gain a better understanding of how COVID-19 vaccines would perform in various populations, it is essential to gather real-world data and analysis postvaccination, in particular concerning different ethnic populations, in order to establish the longterm effectiveness (protection rate) in several different sub-populations. These subpopulations can be defined based on differences in gender, age, nationality, occupation, comorbidities and chronic disease (including haemodialysis and oncology patients).

Therefore, this study was conducted to evaluate the long-term effectiveness (protection rate) of Pfizer-BioNtech BNT162b2 and AstraZeneca-Oxford AZD1222 COVID-19 vaccines in KSA, including national and expatriate subjects from different countries. It also looks at the demographics and clinical characteristics of subjects and the adverse events (AE) postvaccination. 
medRxiv preprint doi: https://doi.org/10.1101/2021.09.18.21263262; this version posted September 22, 2021. The copyright holder for this

\section{Methods}

\section{Subjects and data collection}

In this study, data for 20555 vaccinated subjects were collected from a single vaccination centre at National Guard Health Affairs (NGHA) hospitals in Riyadh city, Saudi Arabia. The subjects received either BNT162b2 or AZD1222 vaccines. Clinical data for all subjects were retrieved from the MNG-HA medical records. Confirmation of COVID-19 infections were obtained from the national database at the Ministry of Health which covers any COVID-19 PCR testing performed in the country. Subjects were given access to an online portal for reporting symptoms and adverse events; in addition, vaccine safety records at the Infection Prevention and Control Department at the King Abdulaziz Medical City (KAMC), MNG-HA, were interrogated. Side effects reports were obtained for around $6 \%$ of the vaccinated subjects. Those who were infected prior to vaccination, had two doses of Pfizer vaccine (who were less than 100 subjects), had the COVID-19 infection within two weeks of vaccination, or lack data on COVID-19 testing were excluded from the analysis presented in this article. Therefore, 18543 out of 20555 subjects were included in the study analysis.

\section{Statistical Analysis}

Descriptive statistics were applied to summarise the data of subjects' demographical and clinical characteristics and the number of adverse events. Comparison between the two study groups (No infection post-vaccination Infection post-vaccination) in terms of demographical and clinical variables, including gender, nationality, and comorbidities where tested using chi-square. Multivariate analysis was applied to model the probability of infection after vaccination using backward elimination logistic regression with alpha level 0.5 to enter the model and 0.05 to stay in the model for all demographical and clinical variables. The final model is reported in terms of 
medRxiv preprint doi: https://doi.org/10.1101/2021.09.18.21263262; this version posted September 22, 2021. The copyright holder for this preprint (which was not certified by peer review) is the author/funder, who has granted medRxiv a license to display the preprint in perpetuity. All rights reserved. No reuse allowed without permission.

odds ratios and $95 \%$ confidence intervals. Using the Wilcoxon rank-sum test, we test the number of days between vaccination and infection for infected individuals in terms of gender, nationality, and comorbidities. All statistical analyses were performed using SAS 9.4 (SAS Institute Inc., Cary, NC) and data visualisation using GraphPad Prism V8 software (GraphPad Software, San Diego, CA).

\section{Ethical approval}

The study was approved by the IRB at KAIMRC for projects RC20/180 and NRC21R-120-03. 
medRxiv preprint doi: https://doi.org/10.1101/2021.09.18.21263262; this version posted September 22, 2021. The copyright holder for this

\section{Results}

\section{Clinical and characteristics of the study cohort}

Data for a total of 18543 subjects were collected from the medical records at King Abdulaziz Medical City, MNG-HA, Riyadh city. Due to vaccine supply issues as well as to achieve a quick rollout of COVID-19 vaccines, KSA has decided to postpone the second dose of COVID-19 vaccines; therefore, all of the study subjects received only a single dose of either BNT162b2 or AZD1222 vaccines between $19^{\text {th }}$ December 2020 and $14^{\text {th }}$ April 2021. Of the included vaccinees, $410(2.3 \%)$ received BNT162b2 and $18133(97.8 \%)$ received AZD1222. Of the total number of vaccinees, 11145 (60.1\%) were males and 7398 (39.1\%) were females. The median age was 33 years (IQR: 26 - 42), ranging from 18 to 112 years old; and the median body mass index (BMI) was 27.3 (IQR: 23.8 - 31.4). Results of SARS-CoV-2 PCR tests were obtained from the national database at the Ministry of Health up $10^{\text {th }}$ August 2021 ; meaning that individuals were followed up for at least three months and almost eight months at maximum.

\section{Effectiveness of COVID-19 vaccines}

Vaccinated subjects who have no documented COVID-19 infection prior to vaccination were analysed in order to provide real-world data on COVID-19 vaccine effectiveness in this cohort. Subjects were followed up for at least three months (last vaccination was on the $14^{\text {th }}$ April and last follow up was on the $10^{\text {th }}$ August). Out of $18543,17091(92.17 \%)$ remained uninfected postvaccination while the infection was documented for $1452(7.83 \%)$ of the vaccinated individuals, Table 1. Forty-six (11.2\% of those who received BNT162b2) and 1406 (7.75\% from those who received AZD1222) had the infection post two weeks of the single dose vaccination, indicating 
medRxiv preprint doi: https://doi.org/10.1101/2021.09.18.21263262; this version posted September 22, 2021. The copyright holder for this

the effectiveness of these vaccines, Table S1. Age does not appear to vary significantly in the two groups of vaccinated subjects (uninfected and infected); median age was 33 (IQR: 26 - 43) for the uninfected group and 33 (IQR: 26 - 41) for the infected group. Likewise, the BMI was similar in the uninfected group (median = 27.3 (IQR: $23.8-31.3)$ and the infected group (median $=28.1$ (IQR: 24.5 - 32.3). In an attempt to identify risk factors associated with infection postvaccination, we analysed the comorbidity data of the subjects in the two groups (Table 1). Male gender and Saudi nationality appeared to have more infection post-vaccination than female and non- Saudi nationality $(p<0.0001)$. Diabetes $(p=0.0325)$, organ (mainly kidney) transplantation $(p=0.0254)$, and morbid obesity $(p=0.0014)$ were found to be associated with the risk of infection in vaccinated subjects. Remarkably, Lung diseases, asthma, or cancer, for which treatment by chemotherapy predisposes patients to microbial infection due to leukocytopenia, did not appear as risk factors of infection in vaccinated subjects. A multivariate logistic regression analysis on infection post-vaccination, demographics and co-morbidities showed that Saudi, male, and obese subjects are more likely to contract COVID-19 post a single dose of COVID-19 vaccines (Table 2). Infections that occur within two weeks of vaccination were only 73 cases and were not included in the study analysis. The data showed that the time between vaccination and infection (excluding the 73 cases) was between 14 and 146 days (median = 82 days), Figure 1. These periods of time were not different when broken by vaccine type (data as per vaccine type is not shown) and COVID-19 cases following the BNT162b2 vaccine were only 46, which does not allow a powerful statistical conclusion on this regard. In addition, these times were not different with regard to subject comorbidities (Table S2). 
Table 1: Co-morbidities and other characteristics of subjects vaccinated with either BNT162b2 or AZD1222 COVID-19 vaccines.

\begin{tabular}{|c|c|c|c|}
\hline & No infection post-vaccination & Infection post-vaccination & D D p \\
\hline & $(n=17091)$ & $(n=1452)$ & \\
\hline Male & $10188(59.62 \%)$ & 957 (65.91\%) & \multirow{2}{*}{$<0.0001$} \\
\hline Female & $6903(40.38 \%)$ & 495 (34.09\%) & \\
\hline \multirow{2}{*}{ Nationality } & Saudi= $12026(70.36 \%)$ & Saudi= 1189 (81.89\%) & \multirow{2}{*}{$<0.0001$} \\
\hline & Non-Saudi= 5065 (29.64\%) & Non-Saudi= 263 (18.11\%) & \\
\hline Diabetes mellitus & $1602(9.37 \%)$ & $161(11.09 \%)$ & 0.0325 \\
\hline Hypertension & $1916(11.21 \%)$ & $62(11.16 \%)$ & 0.9505 \\
\hline Hyperlipidemia & 1009 (5.90\%) & $77(5.30 \%)$ & 0.3494 \\
\hline $\begin{array}{l}\text { Chronic kidney } \\
\text { disease }\end{array}$ & $213(1.25 \%)$ & $18(1.24 \%)$ & 0.9826 \\
\hline $\begin{array}{l}\text { Chronic lung } \\
\text { disease }\end{array}$ & $604(3.53 \%)$ & $61(4.20 \%)$ & 0.1894 \\
\hline Asthma & $578(3.38 \%)$ & 58 (3.99\%) & 0.2182 \\
\hline Malignancy & $183(1.07 \%)$ & $16(1.10 \%)$ & 0.9118 \\
\hline Morbid obesity & $603(3.53 \%)$ & 75 (5.17\%) & 0.0014 \\
\hline Haemodialysis & $93(0.54 \%)$ & $8(0.55 \%)$ & 0.973 \\
\hline Organ Transplant & $11(0.06 \%)$ & $4(0.28 \%)$ & 0.0254 \\
\hline
\end{tabular}


Table 2: Odd ratios from a multivariate logistic regression analysis modelling the probability of COVID-19 infection post-vaccination.

\begin{tabular}{|l|c|l|l|}
\hline Variable & Odds Ratio & Cl & P Value \\
\hline Gender: Male & 1.167 & $1.039-1.311$ & 0.0091 \\
\hline Nationality: Saudi & 1.805 & $1.567-2.079$ & $<0.0001$ \\
\hline Obese & 1.327 & $1.033-1.705$ & 0.0271 \\
\hline
\end{tabular}

\section{Adverse events to COVID-19 vaccines}

To provide insights on the adverse events (AE) to the vaccines in the study subjects, only 1084 subjects utilised the online reporting portal or contacted NGHA hospitals to report AE (Table 3). Although around $5.1 \%$ of the vaccinated subjects reported $\mathrm{AE}$, lack of reporting does not ensure lack of side effects. Injection site pain was the most frequently reported AE (800 cases). Other common AEs include fatigue (732 cases), fever (714 cases), myalgia (678), headache (657 cases), joint pain and malaise (399 cases). In contrast, AEs, such as skin rash, cough, abdominal pain and tachycardia were only reported by single individuals among vaccinated subject. 
Table 3: Reported adverse events post COVID-19 vaccination.

\begin{tabular}{|l|l|l|l|}
\hline \multicolumn{1}{|c|}{ AE } & $\begin{array}{c}\text { \# of } \\
\text { cases }\end{array}$ & \multicolumn{1}{c|}{ AE } & $\begin{array}{c}\text { \# of } \\
\text { cases }\end{array}$ \\
\hline Injection site pain & 800 & Cardiac (Chest pain, palpitation, dyspnea) & 12 \\
\hline $\begin{array}{l}\text { Injection site swelling (and } \\
\text { redness) }\end{array}$ & 216 & Dizziness & 11 \\
\hline Fatigue & 732 & $\begin{array}{l}\text { Gastrointestinal (Abdominal pain, } \\
\text { vomiting, diarrhea) }\end{array}$ & 8 \\
\hline Fever & 714 & Lymphadenopathy & 7 \\
\hline Myalgia & 678 & Skin rash & 4 \\
\hline Headache & 657 & CNS (Syncope, numbness) & 3 \\
\hline Joint pain & 399 & Blurred Vision & 2 \\
\hline Malaise & 399 & Cough & 1 \\
\hline Chills & 312 & Profuse sweat & 1 \\
\hline Nausea & 164 & & \\
\hline
\end{tabular}


medRxiv preprint doi: https://doi.org/10.1101/2021.09.18.21263262; this version posted September 22, 2021. The copyright holder for this

\section{Discussion}

In this study, the long-term effectiveness and self-reported adverse events post-vaccination with two approved COVID-19 vaccines in KSA were evaluated. These vaccines were the PfizerBioNtech BNT162b2 and AstraZeneca-Oxford AZD1222 COVID-19 vaccines. The effectiveness of the BNT162b2 and AZD1222 COVID-19 vaccines is very important for the control of the disease. The current study showed a high rate of protection against infection (92\%) as only $1452(7.83 \%)$ vaccinees had a COVID-19 infection post-vaccination. After excluding any infection that occurred within 2 weeks of single dose vaccinations, the time between vaccination and infection varied from 14 and 146 days (median = 82 days). In a previous study from KSA, the effectiveness of the AZD1222 vaccine was $99.5 \%$ within 3 weeks of the first dose (21). The efficacy of BNT162b2 vaccine in preventing symptomatic COVID-19 infection was 52\% (95\% $\mathrm{Cl}: \square 30-86 \%)$ after one dose and 95\% (95\% Cl: 90-98\%) after two doses in clinical trial settings (8). On the other hand, clinical trials showed an efficacy of $70 \%(95 \% \mathrm{Cl}: \square 55-81 \%)$ after two doses of the AZD1222 vaccine (8). Data from real-world vaccination showed that two doses of BNT162b2 vaccine reduced the risk of SARS-CoV-2 infection by $90 \%$ (22). In addition, it was found that most breakthrough infections were either asymptomatic or mildly symptomatic (23).

In the current study, infection post vaccination were significantly higher in subjects with diabetes mellites, obesity, or organ transplantation. In a previous study, the rate of breakthrough infections was not different among vaccinees by age group, gender, or type of vaccine but were lower among those without comorbidities $(0.44$ [95\% Cl 0.25,0.62]) compared with those with 1 to 3 comorbidities (24). The contribution of underlying disease to breakthrough infections is of particular importance as additional boosting doses might be required. In one study, the immune responses after COVID-19 vaccine was lower among males and those with underlying 
medRxiv preprint doi: https://doi.org/10.1101/2021.09.18.21263262; this version posted September 22, 2021. The copyright holder for this

comorbidities such as diabetes mellitus, hypertension and renal disease (25). A meta-analysis showed that diabetic patients had increased risk for severe COVID-19 and increased mortality (26). A multivariate logistic regression analysis on infection post-vaccination in the current study showed that Saudi, male, and obese subjects were more likely to contract COVID-19 post a single dose of COVID-19 vaccines. The reason for Saudi male to have higher rate of breakthrough infections might be related to the social norms, occupations, and behavioural interactions, warranting further social-epidemiological studies. The contribution of different ethnicity to the development of breakthrough infection was also reported previously $(24,27,28)$.

The percentage of the infected patients in our study would be affected by the endemicity of the virus in the study areas. Additionally, the pandemic has shown frequent waves and variations in the numbers of the daily new cases of COVID-19, which would certainly influence our findings. Emerging variants of the SARS-CoV-2 might have an impact on the vaccine effectiveness, especially for the one dose protection, a strategy that has been followed by several countries due to vaccine logistic issues and the need to expand vaccination coverage in populations. Therefore, long-term follow-up on the vaccinees is needed to estimate the longevity of the single-dose vaccine effect and effectiveness.

Of the 20555 vaccinated subjects, $1084(5.1 \%)$ had utilised the online portal or contacted the hospital to report AEs following the vaccination. In an earlier study on vaccine safety and reactogenicity from $\mathrm{KSA}, 34.7 \%$ reported an adverse event on the first call after the vaccination (21). These differences in the rate of AEs are likely related to the methodology of the two studies. The current study utilised self-reporting and the previous study utilised an active methodology by calling subjects to record any AEs. In the current study, the most reported AEs 
medRxiv preprint doi: https://doi.org/10.1101/2021.09.18.21263262; this version posted September 22, 2021. The copyright holder for this

were injection site pain $(n=800)$, fatigue $(n=732)$, fever $(n=714)$, myalgia $(n=678)$ and headache $(\mathrm{n}=657)$. The previously cited study from KSA also found that local AEs at the injection site were most common after AZD1222 (30.5\%) (21) while the current study cannot establish a rate for this AE due to the used method. In a phase III clinical trial, injection-site pain was reported by $48.6 \%$ (29); however, this rate of occurrence varied for different vaccines (30).

Fever was the most frequently reported adverse effects after COVID-19 vaccination in this study. Two previous studies from KSA reported fever in $18.5 \%$ after the first dose of BNT162b2 vaccine, $1.3 \%$ after the second dose and an overall rate of $4.3 \%$ (31). The second study reported a rate of $31 \%$ after the AZD1222 vaccine $(21)$. In a third study from KSA, fever was reported in $66 \%$ of the subjects who received either AZD1222 or BNT162b2 vaccine (32) while fever was reported in $22 \%$ of participants receiving BNT162b2 vaccine in a randomisedcontrolled trial (33). The current study showed that 7 vaccinees had lymphadenopathy after COVID-19 vaccination. The incidence of ipsilateral axillary reactive lymphadenopathy following mRNA vaccine was $13 \%$ among 68 patients who had CT-scan (34). In addition, 20 vaccinees developed ipsilateral supraclavicular lymphadenopathy in a separate study (35). The estimated occurrence of lymphadenopathy was $1 \%$ and $10 \%$ after the after BNT162b2 and mRNA-1273 vaccines, respectively $(36,37)$. Nevertheless, lymphadenopathy is usually documented following other intramuscular vaccines such as influenza and human papillomavirus vaccines $(38,39)$.

In conclusion, this study is the first to investigate the safety and efficacy of two main vaccines in a large cohort in Saudi Arabia including national and expatriate subjects from different countries. Single-dose COVID-19 vaccines showed an effectiveness rate of $92 \%$ with no major side effects during the three to eight months observational period. 
medRxiv preprint doi: https://doi.org/10.1101/2021.09.18.21263262; this version posted September 22, 2021. The copyright holder for this preprint (which was not certified by peer review) is the author/funder, who has granted medRxiv a license to display the preprint in perpetuity. All rights reserved. No reuse allowed without permission.

\section{Acknowledgments}

The authors are grateful for the assistance of the COVID-19 vaccination center at MNG-HA and the Saudi Ministry of Health.

\section{Funding}

This study was funded by KAIMRC under the grant RC20/180; PI: Naif K. Alharbi.

\section{Conflict of interest}

The authors declare no conflict of interest. 
medRxiv preprint doi: https://doi.org/10.1101/2021.09.18.21263262; this version posted September 22, 2021. The copyright holder for this preprint (which was not certified by peer review) is the author/funder, who has granted medRxiv a license to display the preprint in perpetuity.

\section{References}

1. Phelan AL, Katz R, Gostin LO. The Novel Coronavirus Originating in Wuhan, China: Challenges for Global Health Governance. JAMA [Internet]. 2020;323(8):709-10. Available from: http://www.ncbi.nlm.nih.gov/pubmed/31999307

2. Decaro N, Lorusso A. Novel human coronavirus (SARS-CoV-2): A lesson from animal coronaviruses. Vet Microbiol [Internet]. 2020 May;244:108693. Available from: http://www.ncbi.nlm.nih.gov/pubmed/32402329

3. Wang C, Wang Z, Wang G, Lau JY-N, Zhang K, Li W. COVID-19 in early 2021: current status and looking forward. Signal Transduct Target Ther [Internet]. 2021;6(1):114. Available from: http://www.ncbi.nlm.nih.gov/pubmed/33686059

4. Wu Z, McGoogan JM. Characteristics of and Important Lessons From the Coronavirus Disease 2019 (COVID-19) Outbreak in China: Summary of a Report of 72314 Cases From the Chinese Center for Disease Control and Prevention. JAMA [Internet]. 2020;323(13):1239-42. Available from: http://www.ncbi.nlm.nih.gov/pubmed/32091533

5. WHO. WHO Coronavirus (COVID-19) Dashboard [Internet]. [cited 2021 Sep 5]. Available from: https://covid19.who.int.

6. Adil MT, Rahman R, Whitelaw D, Jain V, Al-Taan O, Rashid F, et al. SARS-CoV-2 and the pandemic of COVID-19. Postgrad Med J [Internet]. 2021 Feb;97(1144):110-6. Available from: http://www.ncbi.nlm.nih.gov/pubmed/32788312

7. Kim JH, Marks F, Clemens JD. Looking beyond COVID-19 vaccine phase 3 trials. Nat Med [Internet]. 2021;27(2):205-11. Available from: http://www.ncbi.nlm.nih.gov/pubmed/33469205

8. Polack FP, Thomas SJ, Kitchin N, Absalon J, Gurtman A, Lockhart S, et al. Safety and Efficacy of the BNT162b2 mRNA Covid-19 Vaccine. N Engl J Med [Internet]. 2020;383(27):2603-15. Available from: http://www.ncbi.nlm.nih.gov/pubmed/33301246

9. Voysey M, Clemens SAC, Madhi SA, Weckx LY, Folegatti PM, Aley PK, et al. Safety and efficacy of the ChAdOx1 nCoV-19 vaccine (AZD1222) against SARS-CoV-2: an interim analysis of four randomised controlled trials in Brazil, South Africa, and the UK. Lancet (London, England) [Internet]. 2021;397(10269):99-111. Available from: http://www.ncbi.nlm.nih.gov/pubmed/33306989

10. Ramasamy MN, Minassian AM, Ewer KJ, Flaxman AL, Folegatti PM, Owens DR, et al. Safety and immunogenicity of ChAdOx $1 \mathrm{nCoV}-19$ vaccine administered in a prime-boost regimen in young and old adults (COV002): a single-blind, randomised, controlled, phase 2/3 trial. Lancet (London, England) [Internet]. 2021;396(10267):1979-93. Available from: http://www.ncbi.nlm.nih.gov/pubmed/33220855

11. Anderson EJ, Rouphael NG, Widge AT, Jackson LA, Roberts PC, Makhene M, et al. Safety and Immunogenicity of SARS-CoV-2 mRNA-1273 Vaccine in Older Adults. N Engl J Med [Internet]. 2020;383(25):2427-38. Available from: http://www.ncbi.nlm.nih.gov/pubmed/32991794 
medRxiv preprint doi: https://doi.org/10.1101/2021.09.18.21263262; this version posted September 22, 2021. The copyright holder for this preprint (which was not certified by peer review) is the author/funder, who has granted medRxiv a license to display the preprint in perpetuity. All rights reserved. No reuse allowed without permission.

12. Walsh EE, Frenck RW, Falsey AR, Kitchin N, Absalon J, Gurtman A, et al. Safety and Immunogenicity of Two RNA-Based Covid-19 Vaccine Candidates. N Engl J Med [Internet]. 2020;383(25):2439-50. Available from: http://www.ncbi.nlm.nih.gov/pubmed/33053279

13. Logunov DY, Dolzhikova I V, Zubkova O V, Tukhvatulin AI, Shcheblyakov D V, Dzharullaeva AS, et al. Safety and immunogenicity of an rAd26 and rAd5 vector-based heterologous primeboost COVID-19 vaccine in two formulations: two open, non-randomised phase 1/2 studies from Russia. Lancet (London, England) [Internet]. 2020;396(10255):887-97. Available from: http://www.ncbi.nlm.nih.gov/pubmed/32896291

14. Zhu F-C, Guan X-H, Li Y-H, Huang J-Y, Jiang T, Hou L-H, et al. Immunogenicity and safety of a recombinant adenovirus type-5-vectored COVID-19 vaccine in healthy adults aged 18 years or older: a randomised, double-blind, placebo-controlled, phase 2 trial. Lancet (London, England) [Internet]. 2020;396(10249):479-88. Available from:

http://www.ncbi.nlm.nih.gov/pubmed/32702299

15. Xia S, Zhang Y, Wang Y, Wang H, Yang Y, Gao GF, et al. Safety and immunogenicity of an inactivated SARS-CoV-2 vaccine, BBIBP-CorV: a randomised, double-blind, placebo-controlled, phase 1/2 trial. Lancet Infect Dis [Internet]. 2021;21(1):39-51. Available from: http://www.ncbi.nlm.nih.gov/pubmed/33069281

16. Keech C, Albert G, Cho I, Robertson A, Reed P, Neal S, et al. Phase 1-2 Trial of a SARS-CoV-2 Recombinant Spike Protein Nanoparticle Vaccine. N Engl J Med [Internet]. 2020;383(24):2320 32. Available from: http://www.ncbi.nlm.nih.gov/pubmed/32877576

17. Jackson LA, Anderson EJ, Rouphael NG, Roberts PC, Makhene M, Coler RN, et al. An mRNA Vaccine against SARS-CoV-2 - Preliminary Report. N Engl J Med [Internet]. 2020;383(20):192031. Available from: http://www.ncbi.nlm.nih.gov/pubmed/32663912

18. Assiri A, Al-Tawfiq JA, Alkhalifa M, Al Duhailan H, Al Qahtani S, Dawas RA, et al. Launching COVID-19 vaccination in Saudi Arabia: Lessons learned, and the way forward. Travel Med Infect Dis. 2021 Jun;43:102119.

19. Public Health Authority. Interim guidelines for the use of SARS-CoV-2 vaccine Riyadh, Saudi Arabia Public Health Authority [Internet]. 2021 [cited 2021 Aug 31]. Available from: https://covid19.cdc.gov.sa/professionals-health-workers/interim-guidelines-for-the-use-of-sarscov-2-vaccine/.

20. Chodick G, Tene L, Rotem RS, Patalon T, Gazit S, Ben-Tov A, et al. The effectiveness of the TWO-DOSE BNT162b2 vaccine: analysis of real-world data. Clin Infect Dis [Internet]. 2021 May 17; Available from: http://www.ncbi.nlm.nih.gov/pubmed/33999127

21. Al Bahrani S, Albarrak A, Alghamdi OA, Alghamdi MA, Hakami FH, Al Abaadi AK, et al. Safety and Reactogenicity of the ChAdOx1 (AZD1222) COVID-19 Vaccine in Saudi Arabia. Int J Infect Dis [Internet]. 2021 Jul 25;110:359-62. Available from: http://www.ncbi.nlm.nih.gov/pubmed/34320413

22. Thompson MG, Burgess JL, Naleway AL, Tyner HL, Yoon SK, Meece J, et al. Interim Estimates 
medRxiv preprint doi: https://doi.org/10.1101/2021.09.18.21263262; this version posted September 22, 2021. The copyright holder for this preprint (which was not certified by peer review) is the author/funder, who has granted medRxiv a license to display the preprint in perpetuity. All rights reserved. No reuse allowed without permission.

of Vaccine Effectiveness of BNT162b2 and mRNA-1273 COVID-19 Vaccines in Preventing SARS-CoV-2 Infection Among Health Care Personnel, First Responders, and Other Essential and Frontline Workers - Eight U.S. Locations, December 2020-March. MMWR Morb Mortal Wkly Rep [Internet]. 2021 Apr 2;70(13):495-500. Available from: http://www.ncbi.nlm.nih.gov/pubmed/33793460

23. Bergwerk M, Gonen T, Lustig Y, Amit S, Lipsitch M, Cohen C, et al. Covid-19 Breakthrough Infections in Vaccinated Health Care Workers. N Engl J Med [Internet]. 2021 Jul 28; Available from: http://www.ncbi.nlm.nih.gov/pubmed/34320281

24. Butt AA, Khan T, Yan P, Shaikh OS, Omer SB, Mayr F. Rate and risk factors for breakthrough SARS-CoV-2 infection after vaccination. J Infect [Internet]. 2021;83(2):237-79. Available from: http://www.ncbi.nlm.nih.gov/pubmed/34052241

25. Lustig Y, Sapir E, Regev-Yochay G, Cohen C, Fluss R, Olmer L, et al. BNT162b2 COVID-19 vaccine and correlates of humoral immune responses and dynamics: a prospective, single-centre, longitudinal cohort study in health-care workers. Lancet Respir Med [Internet]. 2021 Sep;9(9):999-1009. Available from: http://www.ncbi.nlm.nih.gov/pubmed/34224675

26. Mantovani A, Byrne CD, Zheng M-H, Targher G. Diabetes as a risk factor for greater COVID-19 severity and in-hospital death: A meta-analysis of observational studies. Nutr Metab Cardiovasc Dis [Internet]. 2020;30(8):1236-48. Available from: http://www.ncbi.nlm.nih.gov/pubmed/32571616

27. Tirupathi R, Muradova V, Shekhar R, Salim SA, Al-Tawfiq JA, Palabindala V. COVID-19 disparity among racial and ethnic minorities in the US: A cross sectional analysis. Travel Med Infect Dis [Internet]. 38:101904. Available from: http://www.ncbi.nlm.nih.gov/pubmed/33137491

28. Al-Tawfiq JA, Leonardi R, Fasoli G, Rigamonti D. Prevalence and fatality rates of COVID-19: What are the reasons for the wide variations worldwide? Travel Med Infect Dis [Internet]. 35:101711. Available from: http://www.ncbi.nlm.nih.gov/pubmed/32360326

29. Heininger U. Efficacy of Single-Dose Ad26.COV2.S Vaccine against Covid-19. N Engl J Med [Internet]. 2021;385(3):288. Available from: http://www.ncbi.nlm.nih.gov/pubmed/34107178

30. McDonald I, Murray SM, Reynolds CJ, Altmann DM, Boyton RJ. Comparative systematic review and meta-analysis of reactogenicity, immunogenicity and efficacy of vaccines against SARS-CoV2. NPJ vaccines [Internet]. 2021 May 13;6(1):74. Available from:

http://www.ncbi.nlm.nih.gov/pubmed/33986272

31. El-Shitany NA, Harakeh S, Badr-Eldin SM, Bagher AM, Eid B, Almukadi H, et al. Minor to Moderate Side Effects of Pfizer-BioNTech COVID-19 Vaccine Among Saudi Residents: A Retrospective Cross-Sectional Study. Int J Gen Med [Internet]. 2021;14:1389-401. Available from: http://www.ncbi.nlm.nih.gov/pubmed/33907443

32. Alhazmi A, Alamer E, Daws D, Hakami M, Darraj M, Abdelwahab S, et al. Evaluation of Side Effects Associated with COVID-19 Vaccines in Saudi Arabia. Vaccines [Internet]. 2021 Jun 18;9(6). Available from: http://www.ncbi.nlm.nih.gov/pubmed/34207394 
medRxiv preprint doi: https://doi.org/10.1101/2021.09.18.21263262; this version posted September 22, 2021. The copyright holder for this preprint (which was not certified by peer review) is the author/funder, who has granted medRxiv a license to display the preprint in perpetuity. All rights reserved. No reuse allowed without permission.

33. Kadali RAK, Janagama R, Peruru S, Malayala S V. Side effects of BNT162b2 mRNA COVID-19 vaccine: A randomized, cross-sectional study with detailed self-reported symptoms from healthcare workers. Int J Infect Dis [Internet]. 2021 May;106:376-81. Available from: http://www.ncbi.nlm.nih.gov/pubmed/33866000

34. Adin ME, Isufi E, Kulon M, Pucar D. Association of COVID-19 mRNA Vaccine With Ipsilateral Axillary Lymph Node Reactivity on Imaging. JAMA Oncol [Internet]. 2021;7(8):1241-2. Available from: http://www.ncbi.nlm.nih.gov/pubmed/34110378

35. Fernández-Prada M, Rivero-Calle I, Calvache-González A, Martinón-Torres F. Acute onset supraclavicular lymphadenopathy coinciding with intramuscular mRNA vaccination against COVID-19 may be related to vaccine injection technique, Spain, January and February 2021. Euro Surveill [Internet]. 2021;26(10). Available from: http://www.ncbi.nlm.nih.gov/pubmed/33706861

36. The European Medicines Agency (EMA). Summary of product characteristics - Comirnaty [Internet]. [cited 2021 Sep 5]. Available from: https://www.ema.europa.eu/en/documents/productinformation/comirnaty-epar-product-information_en.pdf

37. The European Medicines Agency (EMA). Summary of product characteristics - COVID 19 vaccine Moderna. [Internet]. [cited $2021 \mathrm{Feb} 15]$. Available from:

https://www.ema.europa.eu/en/about-us/who-we-are

38. Shirone N, Shinkai T, Yamane T, Uto F, Yoshimura H, Tamai H, et al. Axillary lymph node accumulation on FDG-PET/CT after influenza vaccination. Ann Nucl Med. 2012 Apr;26(3):24852.

39. Coates EE, Costner PJ, Nason MC, Herrin DM, Conant S, Herscovitch P, et al. Lymph Node Activation by PET/CT Following Vaccination With Licensed Vaccines for Human Papillomaviruses. Clin Nucl Med. 2017 May;42(5):329-34. 
medRxiv preprint doi: https://doi.org/10.1101/2021.09.18.21263262; this version posted September 22, 2021. The copyright holder for this preprint (which was not certified by peer review) is the author/funder, who has granted medRxiv a license to display the preprint in perpetuity.

Figure Legends

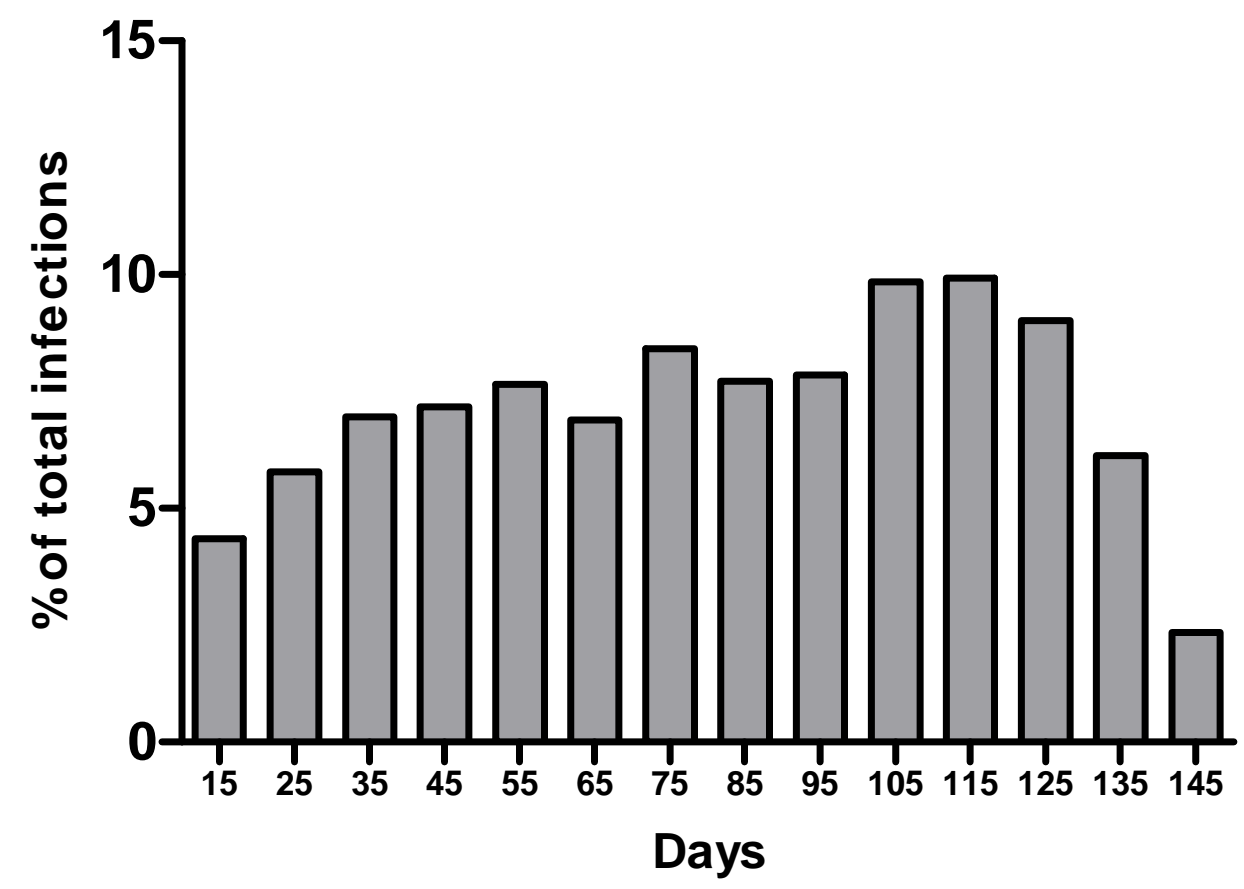

Figure 1: Days between COVID-19 vaccination and infections shown as percentage of the infected subjects. 


\section{Supplementary tables}

Table S1: Co-morbidities and other characteristics of the study subjects (as in Table 1) presented according to the vaccine type.

\begin{tabular}{|c|c|c|c|c|c|c|}
\hline & \multicolumn{3}{|c|}{$\begin{array}{l}\text { Vaccination with Pfizer BNT162b2 COVID-19 } \\
\text { Vaccine }\end{array}$} & \multicolumn{3}{|c|}{$\begin{array}{l}\text { Vaccination with AstraZeneca AZD1222 COVID- } \\
19 \text { Vaccine }\end{array}$} \\
\hline & $\begin{array}{l}\text { No infection } \\
\text { post- } \\
\text { vaccination }\end{array}$ & $\begin{array}{l}\text { Infection post- } \\
\text { vaccination }\end{array}$ & $P$ value & $\begin{array}{l}\text { No infection } \\
\text { post- } \\
\text { vaccination }\end{array}$ & $\begin{array}{l}\text { Infection post- } \\
\text { vaccination }\end{array}$ & $P$ value \\
\hline & $(n=364)$ & $(n=46)$ & & $(n=16727)$ & $(n=1406)$ & \\
\hline Male & $213(63.96 \%)$ & 31 (70.45\%) & $<0.0001$ & $\begin{array}{l}9953 \\
(59.54 \%)\end{array}$ & $924(65.77 \%)$ & $<0.0001$ \\
\hline Female & $120(36.04 \%)$ & $13(29.55 \%)$ & & $\begin{array}{l}6763 \\
(40.46 \%)\end{array}$ & 481 (34.23\%) & \\
\hline \multirow[t]{2}{*}{ Nationality } & $\begin{array}{l}\text { Saudi }=318 \\
(87.4 \%)\end{array}$ & $\begin{array}{l}\text { Saudi }=\quad 43 \\
(93.5 \%)\end{array}$ & 0.2283 & $\begin{array}{l}\text { Saudi= } \\
11708 \\
(69.99 \%)\end{array}$ & $\begin{array}{l}\text { Saudi }= \\
(81.51 \%)\end{array}$ & $<0.0001$ \\
\hline & $\begin{array}{l}\text { Non-Saudi= } \\
46(12.6 \%)\end{array}$ & $\begin{array}{l}\text { Non-Saudi }=3 \\
(6.5 \%)\end{array}$ & & $\begin{array}{l}\text { Non-Saudi= } \\
5019 \\
(30.01 \%)\end{array}$ & $\begin{array}{l}\text { Non-Saudi }=260 \\
(18.49 \%)\end{array}$ & \\
\hline Diabetes & $60(16.5 \%)$ & $2(4.3 \%)$ & 0.0304 & $\begin{array}{l}1542 \\
(9.22 \%)\end{array}$ & $159(11.31 \%)$ & 0.0098 \\
\hline Hypertension & $56(15.4 \%)$ & $4(8.7 \%)$ & 0.2265 & $\begin{array}{l}860 \\
(11.12 \%)\end{array}$ & $158(11.24 \%)$ & 0.8927 \\
\hline Hyperlipidemia & $20(5.5 \%)$ & $1(2.2 \%)$ & 0.492 & 989 (5.91\%) & 76 (5.41\%) & 0.4372 \\
\hline Renal diseases & $35(9.6 \%)$ & $2(4.3 \%)$ & 0.4089 & $178(1.06 \%)$ & 16 (1.14\%) & 0.7961 \\
\hline Lung diseases & $22(6.0 \%)$ & $1(2.2 \%)$ & 0.4947 & $582(3.48 \%)$ & $60(4.27 \%)$ & 0.1246 \\
\hline Asthma & $21(5.8 \%)$ & $1(2.2 \%)$ & 0.492 & $557(3.33 \%)$ & $57(4.05 \%)$ & 0.1494 \\
\hline Cancer & $6(1.6 \%)$ & & 1 & 177 (1.06\%) & $16(1.14 \%)$ & 0.7794 \\
\hline Morbid obesity & $18(4.9 \%)$ & $6(14.0 \%)$ & 0.0402 & 585 (3.50\%) & 69 (4.91\%) & 0.0065 \\
\hline
\end{tabular}


medRxiv preprint doi: https://doi.org/10.1101/2021.09.18.21263262; this version posted September 22, 2021. The copyright holder for this preprint (which was not certified by peer review) is the author/funder, who has granted medRxiv a license to display the preprint in perpetuity.

All rights reserved. No reuse allowed without permission.

\begin{tabular}{|l|l|l|l|l|l|l|}
\hline Haemodialysis & $32(8.8)$ & $2(2.2)$ & 0.4042 & $61(0.36 \%)$ & $6(0.43 \%)$ & 0.7126 \\
\hline Transplant & $1(0.3 \%)$ & $0(0 \%)$ & & $10(0.06 \%)$ & $4(0.28 \%)$ & 0.0192 \\
\hline
\end{tabular}

Table S2: Number of days between vaccination and infection measured for gender, nationality, and comorbidities.

Median (and IQR) of the number of days between vaccination and infection analysed according to comorbidities and other characteristics of the subjects who contracted COVID-19 post-vaccination; excluding infections within two weeks of vaccination.

\begin{tabular}{|l|l|l|l|l|l|}
\hline & \multicolumn{3}{|l|}{ Median (IQR) } & Median (IQR) & P Value \\
\hline Gender & Female & $76(47-112)$ & Male & $86(54-112)$ & 0.0607 \\
\hline Nationality & Saudi & $81(50-111)$ & Non-Saudi & $93(51-115)$ & 0.0624 \\
\hline Diabetes & No & $83(51-112)$ & Yes & $75.5(50-110)$ & 0.2679 \\
\hline Hypertension & No & $83(50-113)$ & Yes & $76(54-107)$ & 0.2129 \\
\hline Hyperlipidemia & No & $83(51-112)$ & Yes & $80(46-105)$ & 0.4144 \\
\hline Renal diseases & No & $82(51-112)$ & Yes & $88(54-113)$ & 0.662 \\
\hline Lung diseases & No & $83(51-112)$ & Yes & $70(37-104)$ & 0.0376 \\
\hline Asthma & No & $83(51-112)$ & Yes & $68.5(37-105)$ & 0.0425 \\
\hline Cancer & No & $82(51-112)$ & Yes & $82(51.5-108)$ & 0.7421 \\
\hline Morbid obesity & No & $83(51.5-112)$ & Yes & $66(44-100)$ & 0.0276 \\
\hline Haemodialysis & No & $82(51-112)$ & Yes & $88(54-89)$ & 0.9363 \\
\hline
\end{tabular}

